ISSN: 2302-8556

E-Jurnal Akuntansi Universitas Udayana

Vol.23.2. Mei (2018): 1600-1628

DOI: https://doi.org/10.24843/EJA.2018.v23.i02.p30

\title{
Pengaruh Religiusitas, Status Sosial Ekonomi dan Love Of Money Pada Persepsi Etis Mahasiswa Akuntansi
}

\author{
A.A. Gde Ari Widhiasmana Pemayun ${ }^{1}$ \\ I Gusti Ayu Nyoman Budiasih ${ }^{2}$ \\ ${ }^{1}$ Fakultas Ekonomi dan Bisnis Universitas Udayana (Unud), Bali, Indonesia \\ email: ariwpemayun@gmail.com /Telp: +62 21266066664 \\ ${ }^{2}$ Fakultas Ekonomi dan Bisnis Universitas Udayana (Unud), Bali, Indonesia
}

\begin{abstract}
ABSTRAK
Penelitian ini bertujuan untuk meneliti pengaruh religiusitas, status sosial ekonomi dan love of money pada persepsi etis mahasiswa akuntansi. Teori Motivasi digunakan untuk menjelaskan hubungan antar variable. Populasi penelitian adalah seluruh mahasiswa aktif program studi akuntansi non reguler angkatan 2014 Fakultas Ekonomi dan Bisnis Universitas Udayana dengan jumlah 187 orang. Sampel penelitian berjumlah 127 orang dengan menggunakan rumus Slovin. Penelitian menggunakan teknik analisis berganda. Data dikumpulkan dengan menggunakan metode kuesioner. Mahasiswa akuntansi dengan tingkat religiusitas yang tinggi akan memiliki persepsi etis yang tinggi. Mahasiswa akuntansi dengan status sosial yang tinggi akan memiliki persepsi etis yang rendah. Mahasiswa akuntansi dengan love of money yang tinggi akan memiliki persepsi etis yang tinggi.

Kata kunci: akuntansi, love of money, mahasiswa, persepsi, religiusitas
\end{abstract}

\begin{abstract}
This study aims to examine the influence of religiosity, socioeconomic status and love of money on the ethical perceptions of accounting students. Motivation theory is used to explain the relationship between variables. The population of the study were all active students of non-regular accounting study program class of 2014 Faculty of Economics and Business Udayana University with the number of 187 people. The sample of study was 127 people using Slovin formula. The research used multiple analysis technique. Data were collected by using questionnaire method. Accounting students with high levels of religiosity will have high ethical perceptions. Accounting students with high social status will have low ethical perceptions. Accounting students with high love of money will have high ethical perceptions.
\end{abstract}

Keywords: accounting, love of money, perception, religiosity, students

\section{PENDAHULUAN}

Kehidupan sehari-hari antar individu ataupun antar kelompok tentunya terdapat nilai yang dijadikan dasar dalam kehidupan bermasyarakat. Lingkungan dan budaya masyarakat berpengaruh pada pandangan akan bagaimana cara berperilaku yang dianggap baik. Perilaku yang dianggap baik dan buruk dari masing-masing daerah disebut dengan norma yang nantinya akan diterapkan 
A.A. Gde Ari W. P. dan I Gusti Ayu Nyoman Budiasih. Pengaruh...

dalam etika berperilaku. Etika merupakan cara pandang bagaimana menilai sesuatu apakah dikatakan baik ataupun buruk. Etika diperlukan dalam masyarakat guna meminimalisir adanya perselisihan antar masyarakat pada suatu pandangan, karena setiap orang tentunya memiliki pandangannya masing-masing. Etika hadir sebagai pedoman masyarakat dalam berperilaku serta menentukan apa yang dianggap baik dan buruk sehingga mampu terciptanya keharmonisan hidup.

Zaman yang semakin maju diberbagai bidang ilmu tanpa disadari secara tidak langsung membentuk sifat manusia yang semakin idealis, intoleran, kapitalis dan semakin rendahnya nilai etika yang dimiliki. Etika tentunya diperlukan dalam kehidupan bermasyarakat, bahkan di zaman yang semakin maju guna tercapainya keharmonisan hidup. Tindakan etis individu dipengaruhi oleh dua faktor utama. Pertama, perilaku tidak etis individu diperngaruhi oleh kepribadian individu itu sendiri. Kedua, perilaku dipengaruhi oleh faktor dari lingkungan individu (Purnamasari, 2006).

Etika dalam masyarakat dapat dikelompokan kedalam dua jenis, yakni etika deskriptif dan normatif. Etika deskriptif lebih menekankan suatu fakta tentang nilai dan perilaku individu pada keadaan yang menjadi kebiasaan di masyarakat. Etika normatif menghimbau dan memberikan penilaian kepada individu akan cara berperilaku sesuai dengan norma yang ada. Etika dianggap penting keberadaanya dalam berbagai aktifitas bermasyarakat, salah satunya dalam bekerja. Etika dalam bekerja atau etika profesi perlu ditumbuhkan demi mencegah tindakan-tindakan yang merugikan orang lain. 
Etika dianggap penting keberadaanya dalam berbagai aktifitas bermasyarakat, salah satunya dalam bekerja. Etika dalam bekerja atau etika profesi perlu ditumbuhkan demi mencegah tindakan-tindakan yang merugikan orang lain. Etika profesi khususnya profesi akuntan sangat penting untuk menjaga integritas dan kredibilitas dalam bekerja.

Etika profesi yang semakin luntur saat ini dapat dilihat dengan maraknya kasus kejahatan yang melibatkan profesi akuntan. Berbagai kasus manipulasi laba baik untuk meningkatkan harga saham ataupun meminimalisir pajak tentunya melibatkan profesi akuntan yang menyusun serta melaporkan kondisi keuangan perusahaan. Akuntan menyalahgunakan kemampuan yang dimilikinya dan melanggar etika yang ada semata untuk mendapatkan keuntungan pribadi dengan melakukan manipulasi laporan keuangan.

Profesi Akuntan saat ini sedang mendapatkan perhatian dari masyarakat dikarenakan banyaknya kasus skandal perusahaan yang melibatkan akuntan beberapa tahun terakhir. Kasus manipulasi laporan keuangan yang dilakukan oleh perusahaan raksasa Toshiba menjadi perhatian serius. Penggelembungan laba perusahaan sebesar Rp.15,85 Triliun oleh perusahaan Toshiba yang dilakukan sejak tahun 2008 telah merugikan para pemegang saham. Kasus manipulasi yang dilakukan perusahaan sebesar Toshiba tentunya berdampak pada menurunnya tingkat kepercayaan masyarakat pada profesi akuntan. Profesi akuntan dipandang negatif dan diragukan kualitasnya dalam memberikan jasa penyusunan laporan keuangan. 
A.A. Gde Ari W. P. dan I Gusti Ayu Nyoman Budiasih. Pengaruh...

Kasus lainnya yang melibatkan profesi akuntan lainnya yakni kasus mega proyek e-KTP yang merugikan negara hingga 2,3 Triliun (news.detik.com). Kasus korupsi pengadaan Al Quran yang melibatkan Kementrian Agama RI menunjukan bahwa kasus etika akuntan juga dapat terjadi dalam lingkungan orang dengan tingkat religiusitas yang tinggi. Kasus korupsi pengadaan Al Quran tahun 20112012 diperkirakan merugikan kas negara hingga Rp. 9,65 miliar (m.tempo.co).

Berbagai kasus manipulasi yang ada secara tidak langsung akan mempengaruhi reaksi dan persepi bagi mahasiswa akuntansi yang akan menjadi seorang akuntan dimasa mendatang. Setiap orang tentunya memiliki nalar, moral dan pandangannya masing-masing, sehingga adanya pendidikan semasa perkuliahan tidak akan menjamin seseorang menjadi seorang akuntan yang baik nantinya. Pendidikan akuntansi tidak mampu memastikan terbentuknya intelektual serta kematangan etis seorang mahasiswa (Gray, Bebbington dan McPhail, 1994). Reaksi mahasiswa pada berbagai kasus kecurangan pelaporan keuangan yang ada dapat dilihat dari sisi religiusitas, status sosial ekonomi dan love of money (kecintaan kepada uang).

Tingkat religiusitas seseorang tidak berpengaruh pada perilaku etisnya (Basri, 2015). Seseorang dengan religiusitas tinggi tidak selalu berperilaku etis. Terdapat perbedaan pendapat terkait hubungan religiusitas dan perilaku etis. Religiusitas mampu mempengaruhi etika bisnis (Peterson et al. 2010) setuju bahwa religiusitas berpengaruh pada persepsi etis mahasiswa akuntansi. Selain religiusitas, status sosial ekonomi diduga menjadi faktor yang mendorong seseorang untuk berperilaku tidak etis. 
Status sosial ekonomi sebagai ukuran posisi seseorang bisa dilihat dari aspek pekerjaan, penghasilan dan posisinya dalam kelompok masyarakat. Status sosial ekonomi memberikan gambaran posisi seseorang dilihat dari aspek sosial maupun ekonomi misalkan pendapatan, kekuasaan dan hal lainnya. Seseorang dengan status sosial ekonomi yang baik cenderung akan bersikap lebih konsumtif, tidak etis, dan mementingkan dirinya sendiri (Prasastianta, 2011). Orang yang memiliki status sosial ekonomi tinggi umumnya tidak akan berperilaku etis (Sipayung, 2015). Tingkat status sosial ekonomi yang berlebih cenderung membuat seseorang merasa lebih berkuasa dan tidak peduli dengan kepentingan orang lain. Status sosial yang tinggi akan menghasilkan kecintaan terhadap uang yang tinggi pula, hal ini dapat membuat seseorang menjadi tamak. Terdapat perbedaan pendapat terkait hubungan status sosial ekonomi dan perilaku etis. Status sosial ekonomi tidak akan berdampak terhadap sikap love of money yang merupakan akar perilaku tidak etis (Pradanti dan Prastiwi, 2014). Disamping status sosial ekonomi, kecintaan pada uang juga dapat mempengaruhi perilaku etis seseorang.

Seseorang dengan kecintaan uang yang tinggi cenderung melakukan tindakan tidak etis (Tang dan Chiu, 2003), namun kecintaan seseorang pada uang dapat digunakan sebagai alat pengendali perilaku tidak etis seseorang (LunaArocas dan Tang, 2004). Seseorang dengan kecintaan uang yang tinggi mampu dikendalikan untuk melakukan tindakan etis dengan adanya perbaikan hasil pendapatan yang mereka peroleh. Kecintaan pada uang dapat mengendalikan perilaku etis seseorang (Luna-Arocas dan Tang, 2004). Apabila seseorang 
A.A. Gde Ari W. P. dan I Gusti Ayu Nyoman Budiasih. Pengaruh...

mendapatkan kepuasan pada apa yang diperoleh dalam hal ini uang, mereka dapat dikendalikan untuk melakukan segala sesuatu sesuai dengan perilaku etis. Love of money dianggap sebagai pemicu timbulnya tindakan tidak etis, namun apabila dapat dikelola dengan baik sikap love of money mampu mengendalikan seseorang untuk berperilaku etis.

Money Ethic Scales (MES) merupakan alat ukur mengenai seberapa jauh perasaan subjektif seseorang pada uang (Tang dan Chiu, 2003) sebagai pengembangan secara general dari penelitian terdahulu seperti yang dilakukan oleh Maslow (1955), Furnham (1984) mengenai perilaku seseorang pada uang. Teori Money Ethic Scales (MES) bila disederhanakan, maka faktor yang mempengaruhi kecintaan seseorang pada uang diantaranya apresiasi, berkuasa, pengelolaan pada uang serta pujian pada diri.

Berdasarkan uraian diatas maka pokok permasalahan dalam penelitian ini yaitu: 1) Bagaimana pengaruh religiusitas pada persepsi etis mahasiswa akuntansi?; 2) Bagaimana pengaruh status sosial ekonomi pada persepsi etis mahasiswa akuntansi?; 3) Bagaimana pengaruh love of money pada persepsi etis mahasiswa akuntansi? Tujuan yang ingin dicapai dalam penelitian ini yaitu : 1) Mendapat bukti empiris tentang pengaruh religiusitas pada persepsi etis mahasiswa akuntansi.; 2) Mendapat bukti empiris tentang pengaruh status sosial ekonomi pada persepsi etis mahasiswa akuntansi.; 3) Mendapat bukti empiris tentang pengaruh love of money pada persepsi etis mahasiswa akuntansi.

Penelitian ini dapat memberikan kontribusi dalam memperkuat bukti empiris dan dijadikan perbandingan, pengembangan dan penyempurnaan dari 
penelitian yang telah dilakukan sebelumnya. Hasil penelitian ini dapat dipergunakan pihak kampus Fakultas Ekonomi dan Bisnis Universitas Udatana dalam memperbaiki sistem pendidikan mahasiswa program studi akuntansi yang akan menjadi seorang akuntan kedepannya.

Teori motivasi menjelaskan bahwa terdapat suatu dorongan atau alasan bagi seseorang untuk melakukan dan menyelesaikan sesuatu (Frederickson, Miller dan Cline, 2008). Dengan adanya motivasi, seseorang akan memiliki tujuan yang ingin dicapai. Teori motivasi oleh Maslow menjelaskan bahwa seseorang memiliki kebutuhan fisiologis, yakni kebutuhan akan makanan, tempat tinggal, serta pendapatan (Hasibuan, 2011). Seseorang akan memiliki motivasi untuk bekerja guna memenuhi kebutuhannya. Status sosial ekonomi dan kecintaan seseorang pada uang erat kaitannya dengan keinginan manusia untuk memenuhi kebutuhannya berdasarkan teori motivasi. Dalam teori motivasi, terdapat kebutuhan akan berafiliasi yang erat kaitannya dengan tingkat religiusitas. Seseorang yang tidak berafiliasi cenderung memiliki kepercayaan pada Tuhan yang rendah (Grasmick, Bursik dan Cochran, 1991). Teori motivasi digunakan untuk menjelaskan hubungan religiusitas, status sosial ekonomi, love of money pada persepsi etis mahasiswa akuntansi.

Kerangka konseptual merupakan hubungan antara kajian empiris dan landasan teorinya. Kerangka konseptual menggambarkan hubungan antar variabel penelitian. 
Pengaruh Religiusitas, Status Sosial Ekonomi dan Love of Money pada Persepsi Etis Mahasiswa Akuntansi

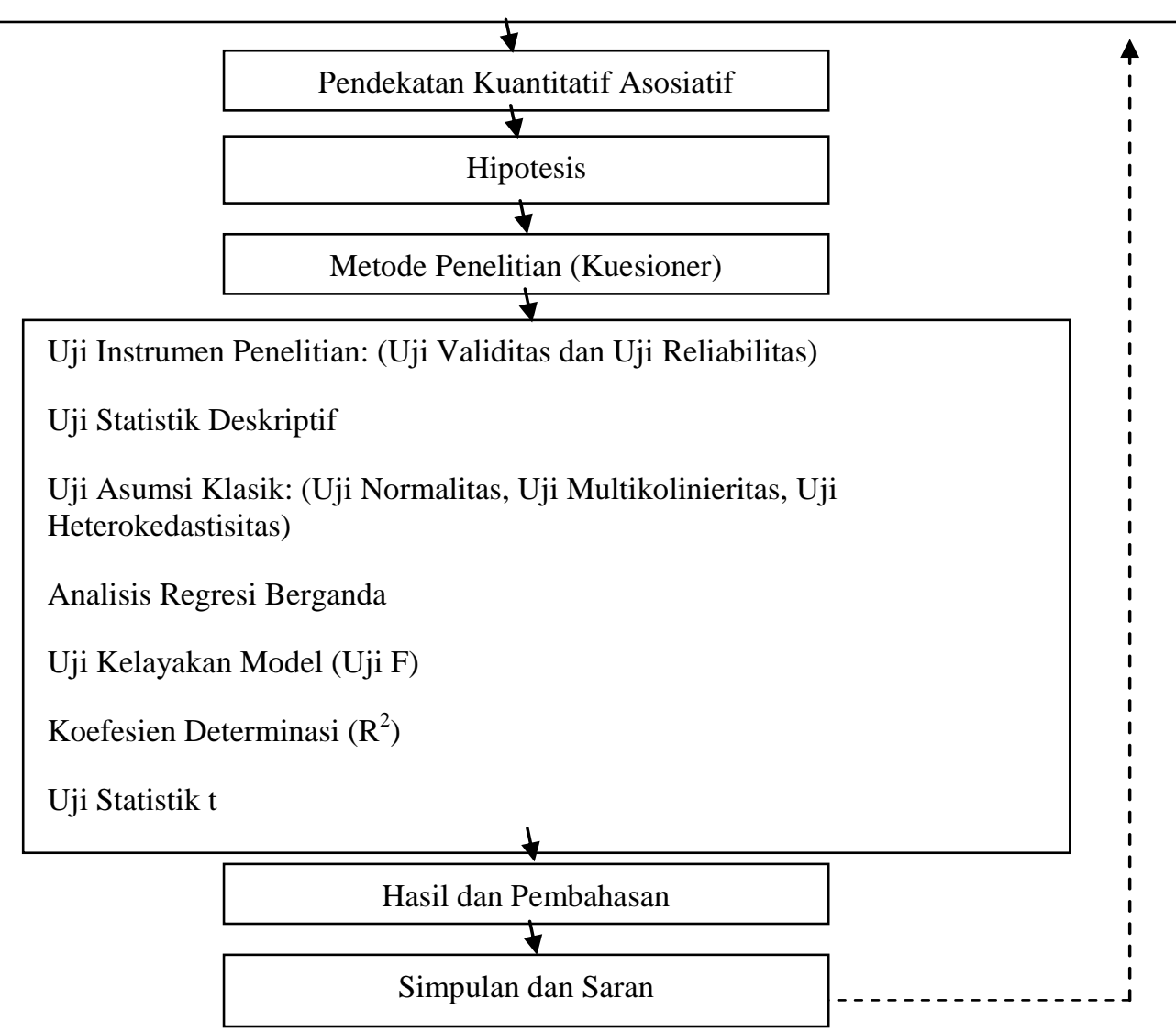

Sumber : Data diolah, 2017

Gambar 1. Kerangka Konseptual

Religiusitas merupakan tingkat kepercayaan atau nilai agama yang dianut seseorang. Agama ada untuk menekan perilaku buruk dan menciptakan keharmonisan hidup. Semua agama memiliki tujuan yang baik. Religiusitas mencakup aturan-aturan dan kewajiban yang bertujuan untuk mengikat dan mengutuhkan seseorang dalam hubungannya dengan Tuhan, antar manusia, dan lingkungan.

Religiusitas dianggap mampu mengontrol perilaku seseorang. Seseorang dengan tingkat religiusitas yang tinggi akan dapat mengontrol dirinya untuk 
melakukan tindakan etis, hal ini sesuai dengan ajaran agama untuk berbuat baik dan tidak merugikan orang lain. Keyakinan agama yang tinggi tentunya dapat mencegah orang melakukan tindakan tidak etis dengan adanya rasa bersalah apabila melanggar ajaran agama (Grasmick, Bursik dan Cochran, 1991). Komitmen agama dipergunakan sebagai pedoman dalam mengukur tingkat religiusitas seseorang yang dilihat dari penerapan nilai agama, keyakinan serta keyakinan dalam kehidupan sehari-sehari.

Religiusitas dapat dikategorikan menjadi lima dimensi (Glock, 1962). Dimensi pertama adalah dimensi ideologis, dimana individu mengikuti aturan tertentu. Dimensi kedua adalah ritualistik, bagaimana seseorang dalam prakteknya mengikuti berbagai ajaran ilmu agama. Ketiga adalah dimensi pengalaman religiusitas. Keempat, dimensi intelektual yang menekankan pada pengetahuan dibidang agama. Kelima adalah dimensi konsekuensial dipergunakan mendeteksi efek kepatuhan seseorang pada keempat dimensi sebelumnya.

Seseorang yang terlihat memiliki religiusitas tinggi tidak selalu menjamin bahwa dirinya sebagai orang baik. Hal ini dibuktikan dengan banyak kasus kejahatan yang melibatkan orang religius. Kasus korupsi pengadaan Al-Quran oleh Kementrian Agama Republik Indonesia menjadi salah satu bukti bahwa seseorang dengan religiusitas tinggi tidak selalu berbuat etis. Rendahnya pemahaman serta keyakinan akan agama dari dalam diri seseorang menjadi penyebab maraknya kasus yang melibatkan orang religius.

Seseorang yang terlihat religius tentunya lebih dipercaya oleh orang lain, hal ini mendorong banyak orang ingin terlihat religius tanpa sepenuhnya mengerti 
A.A. Gde Ari W. P. dan I Gusti Ayu Nyoman Budiasih. Pengaruh...

akan ajaran agama dan komitmen dalam mematuhi berbagai aturan yang ada. Hal ini menjelaskan bahwa tingkat religiusitas seseorang tidak berpengaruh pada perilaku etisnya (Basri, 2015).

Teori motivasi mengungkapkan bahwa setiap orang tentunya memiliki kebutuhan yang harus dipenuhi, mulai dari kebutuhan dasar hingga kebutuhan lainnya. Dorongan untuk memenuhi kebutuhan tanpa adanya keahlian dan kesempatan membuat seseorang mampu melakukan berbagai cara, sekalipun tidak etis guna mencapai tujuan. Agama berperan untuk mencegah timbulnya tindakan tidak etis seseorang dalam memenuhi kebutuhannya, karena didalam agama dijelaskan untuk selalu berbuat baik dan tidak merugikan orang lain. Seseorang akan merasa takut dikucilkan apabila dirinya dinilai tidak beragama dan berbuat tidak baik dalam masyarakat.

Terdapat beberapa hasil penelitian terkait hubungan religiusitas dengan persepsi etis mahasiswa. Religiusitas berpengaruh positif pada etika bisnis. Religiusitas berpengaruh pada persepsi etis mahasiswa akuntansi (Peterson et al., 2010). Religiusitas tentunya akan mempengaruhi persepsi etis mahasiswa akuntansi. Berdasarkan penjelasan yang ada, dapat diajukan hipotesis:

$\mathrm{H}_{1}$ : Religiusitas berpengaruh positif pada persepsi etis mahasiswa akuntansi.

Status sosial ekonomi sebagai kondisi kemampuan finansial keluarga dan perlengkapan material yang dimiliki (Basrowi dan Siti, 2010). Status sosial ekonomi sebagai gambaran keadaan seseorang yang ditinjau dari segi sosial dan ekonomi, seperti tingkat pendidikan, tingkat pendapatan, dan sebagainya (Prasastianta, 2011). Status sosial ekonomi erat kaitannya dengan pendapatan dan 
keinginan berkuasa. Seseorang dengan status sosial ekonomi yang tinggi, cenderung memiliki banyak uang dan bersikap konsumtif. Seseorang dengan perilaku konsumtif biasanya tidak mementingkan etika karena merasa berkuasa dengan memiliki banyak uang.

Seseorang dengan status sosial yang tinggi umumnya menginginkan kekuasaan, dihormati, dan menganggap rendah orang lain. Pengujian yang dilakukan oleh Prasastianta (2011) menguji faktor yang mendorong perilaku ekonomi adalah status sosial ekonomi mahasiswa. Hasil tersebut menunjukan bahwa mahasiswa dengan status sosial ekonomi perilaku etisnya cenderung rendah dan hanya mementingkan dirinya sendiri. Status sosial ekonomi erat kaitannya dengan sifat tamak dan egois.

Semua orang melakukan pekerjaan dengan motivasi yang berbeda-beda (Noe dan Liu, 2006). Motivasi utama yakni keinginan mendapatkan pendapatan yang lebih besar guna memenuhi kebutuhan dan meningkatkan kebanggaan akan status sosial ekonomi yang dimilikinya, hal ini sesuai dengan teori motivasi terkait kebutuhan akan adanya pengakuan dan penghargaan diri. Seseorang akan menggunakan cara apapun untuk mendapatkan penghargaan diri oleh masyarakat, sehingga status sosial ekonomi dirasa akan sangat berpengaruh pada timbulnya perilaku yang tidak etis. Seseorang dapat melakukan tindakan tidak etis pada kondisi status sosial ekonomi yang berbeda (Danta dan Ginting, 2003). Semakin tinggi status sosial ekonomi seseorang, mereka cenderung bersifat konsumtif (Sipayung, 2015). Perilaku konsumtif kerap membuat mereka berperilaku tidak etis. Berdasarkan penjelasan yang ada, dapat diajukan hipotesis: 
A.A. Gde Ari W. P. dan I Gusti Ayu Nyoman Budiasih. Pengaruh...

$\mathrm{H}_{2}$ : Status sosial ekonomi berpengaruh negatif pada persepsi etis mahasiswa akuntansi.

Love of money sangat berkaitan dengan sifat tamak dan rakus. Seseorang dengan love of money yang tinggi cenderung memiliki kecintaan berlebihan pada uang dan akan menilai segala sesuatu hal dengan uang. Hasibuan (2011) menjelaskan bahwa manusia memiliki beberapa kebutuhan yang diklasifikasikan kedalam beberapa tingkatan, yakni: fisiologis, kebutuhan rasa aman, harga diri dan kebutuhan aktualisasi. Kebutuhan tersebut dapat terpenuhi dengan adanya uang, namun tingkat kecintaan seseorang pada uang yang berlebih dapat menimbulkan ketamakan.

Seseorang cenderung akan melakukan apapun demi mendapatkan uang, termasuk berperilaku tidak etis. Seseorang dengan love of money yang rendah cenderung memiliki kepuasan kerja yang rendah pula. Love of money dan persepsi memiliki hubungan yang negatif. Terdapat beberapa hasil penelitian yang mengukur pengaruh love of money pada perilaku etis seseorang.

Teori motivasi erat kaitannya dengan sifat tamak seseorang akan keingananya terhadap uang. Uang membuat seseorang mampu memenuhi berbagai kebutuhan dasar dalam teori motivasi. Semakin tinggi hasrat seseorang memenuhi kebutuhannya dan kecintaannya pada uang, semakin tinggi pula kemungkinan orang tersebut berperilaku tidak etis. Desakan dalam memenuhi kebutuhan akan membuat seseorang berperilaku tidak etis.

Hasil penelitian Charismawati (2011) pada persepsi etis mahasiswa akuntansi menunjukan hubungan negatif antara love of money dengan persepsi etis mahasiswa akuntansi. Semakin tinggi kecintaan seseorang pada uang, maka akan 
semakin tidak etis perilaku seseorang. Love of money memiliki hubungan negatif dengan perilaku etis (Aziz, 2015). Etika uang seseorang akan berpengaruh langsung dan signifikan pada perilaku tidak etis (Tang dan Chiu, 2003). Berdasarkan uraian diatas maka diajukan hipotesis:

$\mathrm{H}_{3}$ : Love of money berpengaruh negatif pada persepsi etis mahasiswa akuntansi.

\section{METODE PENELITIAN}

Desain penelitian menggambarkan keseluruhan penelitian, mulai dari masalah penelitian, hipotesis, pengolahan dan analisis data yang akhirnya akan dibahas dan diinterpretasikan sehingga ditarik kesimpulan dan saran bagi penelitian selanjutnya. Desain penelitian dapat dilihat dalam Gambar 2.

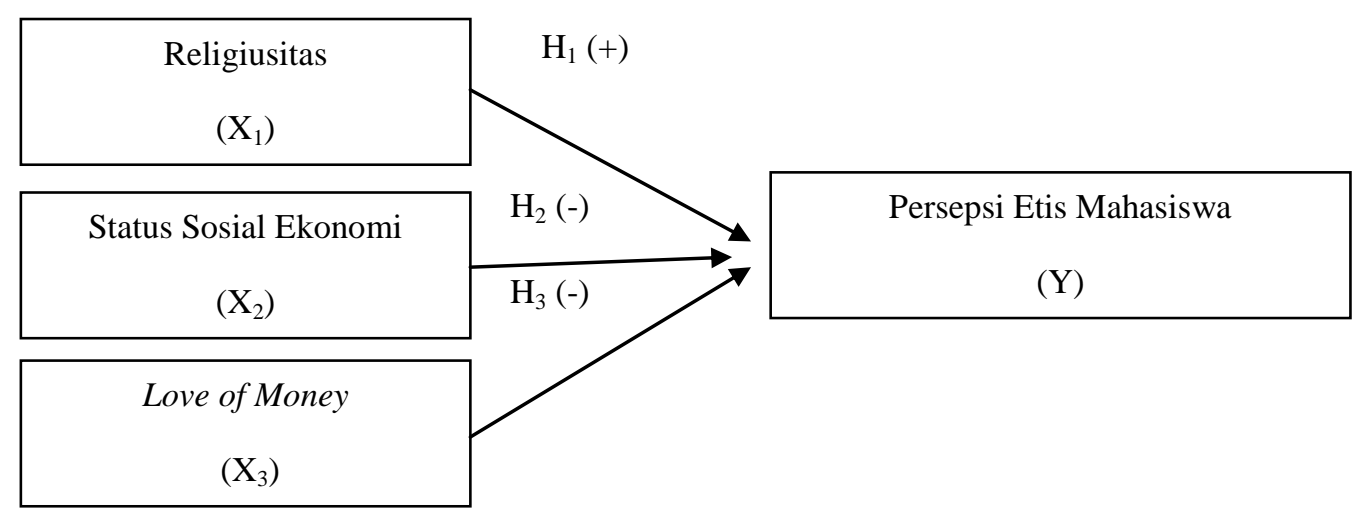

\section{Gambar 2. Desain Penelitian}

Sumber : Data diolah, 2017

Penelitian dilaksanakan di Fakultas Ekonomi dan Bisnis program studi akuntansi angkatan 2014 Program S1 non reguler dengan menyebarkan kuisioner yang beralamat di Jalan P. B. Sudirman, Denpasar. Objek dalam penelitian ini adalah persepsi mahasiswa semester 7 angkatan 2014, program studi akuntansi Fakultas Ekonomi dan Bisnis Non Reguler Univesitas Udayana dalam pengaruh religiusitas, status sosial ekonomi, love of money pada persepsi etis mahasiswa 
A.A. Gde Ari W. P. dan I Gusti Ayu Nyoman Budiasih. Pengaruh...

akuntansi.Variabel independen dalam penelitian ini yaitu religiusitas $\left(\mathrm{X}_{1}\right)$, status sosial ekonomi $\left(\mathrm{X}_{2}\right)$ dan love of money $\left(\mathrm{X}_{3}\right)$. Variabel dependen dalam penelitian ini adalah persepsi etis mahasiswa akuntansi (Y).

Religiusitas berkaitan dengan perilaku etis seseorang. Religiusitas menekankan pada seberapa jauh hubungan antar manusia dengan Tuhan (ilmu agama). Orang dengan ilmu agama yang baik cenderung akan berperilaku baik dan etis sesuai dengan ajaran agama. Teknik untuk mengukur tingkat religiusitas yakni dengan menggunakan kuisioner yang dikembangkan oleh Pope dan Mohdali (2010) dengan skala likert 5 poin. Indikator dalam penilaian ini mengacu pada kelima dimensi religiusitas (Glock, 1962) yakni dimensi ideologis, dimensi ritualistik, dimensi pengalaman religiusitas, dimensi intelektual, dan dimensi konsekuensial.

Status sosial ekonomi menggambarkan kemampuan sosial dan ekonomi seseorang yang dapat diukur dari pendapatan, kekuasaan dan posisi dalam lingkungan masyarakat (Prasastianta, 2011). Status sosial ekonomi berpengaruh pada keinginan berkuasa dan perilaku tidak etis. Teknik yang digunakan dalam mengukur tingkat status sosial ekonomi yakni menggunakan indikator jumlah penghasilan gabungan orang tua, pendidikan terakhir orang tua, jenis pekerjaan orang tua, dan jumlah kekayaan yang dimiliki kedalam 5 kategori (Adi, Rianto, 2008, Metodologi Penelitian Sosial dan Hukum, Yayasan Obor Indonesia, Jakarta).

Love of money atau kecintaan seseorang pada uang tentunya akan berpengaruh pada perilaku etis seseorang. Sifat cinta uang akan membuat 
seseorang menjadi tamak dan mentoleransi tindakan tidak etis guna mendapatkan uang. Kecintaan pada uang dapat dihitung dengan metode Money Ethic Scale (MES) yang diperluas oleh Luna-Arocas dan Tang (2004), dengan skala likert 5 poin.

Persepsi adalah bagaimana seseorang menilai suatu pelanggaran. Persepsi etika diukur dengan cara menggunakan metode oleh Richmond (2001). Ethical Rating (ERATING) memuat 8 pertanyaan dengan rentang skala 1-5 untuk menilai persepsi etika. Poin 1 (sangat tidak setuju) yang berarti tindakan sangat etis dan poin 5 (sangat setuju) yang berarti tindakan sangat tidak etis.

Populasi dari penelitian merupakan seluruh mahasiswa aktif non reguler program studi akuntansi angkatan 2014 Fakultas Ekonomi dan Bisnis Universitas Udayana. Populasi penelitian ini berjumlah 187 orang. Alasan pemilihan mahasiswa aktif non reguler program studi akuntansi angkatan 2014 dikarenakan mahasiswa non regular sebagian diantaranya telah bekerja (34\%) dan berbisnis $(22,7 \%)$ berdasarkan hasil kuesioner dengan 97 orang responden. Mahasiswa dengan fokus bekerja setelah lulus sebesar 68\%, berbisnis 21,6\%, dan melanjutkan pendidikan sebesar $0,3 \%$.

Teknik penentuan sampel dalam penelitian ini menggunakan probability sampling dengan menggunakan teknik random sederhana. Teori Sovlin (dalam Umar 2003:108) digunakan dalam penentuan jumlah sampel dengan tingkat ketelitian 5\%, sehingga didapat sampel berjumlah 127 mahasiswa.

$$
\mathrm{n}=\frac{N}{1+N(e)^{2}}
$$




$$
\begin{array}{ll}
\text { Keterangan: } & \mathrm{n}=\text { ukuran sampel } \\
& \mathrm{N}=\text { ukuran populasi } \\
& \mathrm{e}=\text { ukuran ketelitian }(5 \%)
\end{array}
$$

Sehingga:

$$
\begin{aligned}
& \mathrm{n}=\frac{186}{1+186(0,05)^{2}} \\
& \mathrm{n}=\frac{186}{1,465} \\
& \mathrm{n}=126.96
\end{aligned}
$$

Jenis data yang dipergunakan adalah data kuantitatif dimana memuat angka atau data kualitatif yang dikelompokan kemudian diberi penilaian berupa angka. Jumlah repsonden yang mengisi kuisioner merupakan data kuantitatif penelitian. Data primer pada penelitian ini adalah hasil dari penilaian responden pada kuisioner yang terdiri dari butir pernyataan dengan skala likert 5 poin untuk variabel religiusitas, status sosial ekonomi, love of money, persepsi etis mahasiswa akuntansi.

Teknik analisis regresi linier berganda digunakan untuk menemukan solusi dari permasalahan penelitian. Teknik analisis linier berganda mampu mengukur pengaruh antara berberapa variabel bebas dengan variabel terikatnya (Ghozali, 2013). Model regresi dalam penelitian ini dinyatakan sebagai berikut.

$$
Y=\alpha+\beta_{1} X_{1}+\beta_{2} X_{2}+\beta_{3} X_{3}+\varepsilon
$$

Keterangan:

$$
\begin{array}{ll}
\mathrm{Y} & \text { : Persepsi Etis } \\
\alpha & \text { : Konstanta } \\
\beta & : \text { Koefisien Regresi } \\
\mathrm{X}_{1} & \text { : Religiusitas } \\
\mathrm{X}_{2} & \text { : Status Sosial Ekonomi } \\
\mathrm{X}_{3} & \text { : Love of Money } \\
e & \text { : error }
\end{array}
$$




\section{HASIL DAN PEMBAHASAN}

Variabel religiusitas, status sosial ekonomi, love of money dan persepsi etis mahasiswa akuntansi dikatakan valid karena hubungan antara nilai pernyataan dengan nilai totalnya lebih besar dari 0,361. Nilai untuk cronbach's alpha masing-masing variabel lebih besar dari 0,60 jadi dapat dinyatakan semua variabel reliable dan dapat dipergunakan dalam penelitian. Tabel menggambarkan hasil analisis statistik deskriptif penelitian sebagai berikut.

Tabel 1.

Hasil Statistik Deskriptif

\begin{tabular}{cccccc}
\hline & N & Minimum & Maximum & Mean & Std. Deviation \\
\hline X1 & 127 & 3.36 & 5.00 & 4.4510 & .36046 \\
X2 & 127 & 1.75 & 5.00 & 3.3701 & .78037 \\
X3 & 127 & 1.35 & 5.00 & 3.3684 & .67019 \\
Y & 127 & 1.13 & 5.00 & 2.7965 & .76201 \\
Valid N (listwise) & 127 & & & &
\end{tabular}

Berdasarkan data pada Tabel dapat diketahui jumlah populasi (N) penelitian ini sebanyak 127 orang. Variabel religiusitas memiliki nilai terendah sebesar 3,36 dan nilai tertinggi sebesar 5,00 serta rata-rata nilainya sebesar 4,451 dan standar deviasi sebesar 0,360. Variabel status sosial ekonomi memiliki nilai terendah sebesar 1,75 dan nilai tertinggi sebesar 5,00 serta rata - rata nilainya sebesar 3,370 dan standar deviasi sebesar 0,780. Love of money mempunyai nilai terendah 1,35 dan nilai tertinggi 5,00 serta nilai mean 3,368 dan standart deviation sebesar 0,670. Persepsi etis mahasiswa akuntansi memiliki nilai terendah sebesar 1,13 dan nilai tertinggi sebesar 5,00 serta rata - rata nilainya sebesar 2,7965 dan standar deviasi sebesar 0,762. Hasil pengujian normalitas, uji multikolinearitas dan uji heteroskedastisitas dapat dilihat pada tabel berikut. 
Tabel 2.

Hasil Uji Asumsi Klasik

\begin{tabular}{lcccc}
\hline \multicolumn{1}{c}{ Variabel } & $\begin{array}{c}\text { Normalitas } \\
\text { Sig. 2 Tailed }\end{array}$ & \multicolumn{2}{c}{ Multikolinearitas } & Heteroskedastisitas \\
Tolerance & VIF & Signifikansi \\
\hline $\begin{array}{l}\text { Religiusitas } \\
\begin{array}{l}\text { Status Sosial } \\
\text { Ekonomi }\end{array}\end{array}$ & 0,939 & 1,064 & 1 \\
Love of money & 0,20 & 0,954 & 1,048 & 1 \\
S & & 0,912 & 1,096 & 1 \\
\hline
\end{tabular}

Sumber: Data diolah, 2017

Hasil uji Kolmogorov-Smirnov pada tabel menunjukan nilai signifikansi yang lebih besar dari 0,05 . Hal ini menjelaskan bahwa data telah berdistribusi secara normal dan dapat dipergunakan dalam penelitian. Variabel religiusitas, status sosial ekonomi dan love of money memiliki nilai tolerance lebih besar dari 0,10 dan memiliki nilai VIF kurang dari 10. Hasil tersebut menunjukan bahwa variabel religiusitas, status sosial ekonomi dan love of money tidak memiliki gejala multikolinearitas. Tabel menunjukan hasil uji heteroskedastisitas dimana seluruh variabel memiliki nilai signifikansi di atas 0,05 sehingga model regresi ini tidak adanya gejala heteroskedastisitas.

Tabel 3.

Hasil Statistik Deskriptif

\begin{tabular}{lccccc}
\hline Model & B & $\begin{array}{c}\text { Unstandardized } \\
\text { Coefficient } \\
\text { Std. Error }\end{array}$ & $\begin{array}{c}\text { Standardized } \\
\text { Coefficient } \\
\text { Beta }\end{array}$ & $\mathbf{t}$ & Sig. \\
\hline 1 (Constant) & $(0.39)$ & 0.68 & & -0.57 & 0.57 \\
$\quad$ X1 & 0.35 & 0.15 & 0.17 & 2.32 & 0.02 \\
X2 & $(0.19)$ & 0.07 & $(0.19)$ & $(2.67)$ & 0.01 \\
X3 & 0.67 & 0.08 & 0.59 & 8.01 & 0.00 \\
F hitung & $: 27.42$ & & & & \\
Signifikansi F & $: 0.00$ & & & & \\
R Square & $: 0.40$ & & & & \\
Adjusted R Square $: 0.39$ & & & & \\
\hline
\end{tabular}

Sumber: Data diolah, 2017 
Berdasarkan hasil analisis yang disajikan pada Tabel 4 maka dapat disusun persamaan regresi sebagai berikut.

$$
Y=-0,39+0,35 X_{1}-0,19 X_{2}+0,67 X_{3}
$$

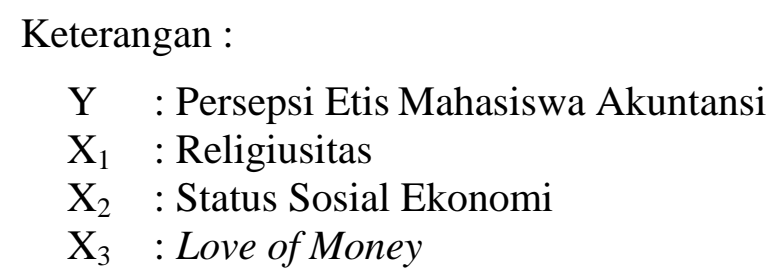

Nilai koefisien $\left(\beta_{1}\right) 0,35$. $\beta_{1}$ positif memperlihatkan jika religiusitas satu satuan meningkat maka persepsi etis mahasiswa akuntansi akan meningkat 0,35 satuan. Nilai koefisien $\left(\beta_{2}\right)-0,19 . \beta_{2}$ negatif membuktikan jika status sosial ekonomi satu satuan meningkat maka persepsi etis mahasiswa akuntansi akan menurun 0,19 satuan. Nilai koefisien $\left(\beta_{3}\right) 0,67$. $\beta_{3}$ positif memperlihatkan jika love of money satu satuan meningkat maka persepsi etis mahasiswa akuntansi akan meningkat 0,67 satuan.

Hasil uji F pada Tabel 4. menunjukkan bahwa F hitung memiliki nilai sebesar 27,42 dan signifikansi nilai uji F sebesar 0,00 dimana nilainya tidak lebih dari 0,05 yang berarti $\mathrm{H}_{1}$ diterima dan $\mathrm{H}_{0}$ ditolak. Hasil ini menunjukan bahwa variabel religiusitas, status sosial ekonomi, love of money pantas dipilih untuk mmperkirakan variabel persepsi etis mahasiswa akuntansi di Fakultas Ekonomi dan Bisnis Universitas Udayana.

Adjusted $R^{2}$ memiliki nilai sebesar 0,39. Hal ini menunjukan 39 persen variasi besarnya persepsi etis mahasiswa akuntansi dapat dijelaskan oleh 
A.A. Gde Ari W. P. dan I Gusti Ayu Nyoman Budiasih. Pengaruh...

religiusitas, status sosial ekonomi, love of money. Sedangkan sisanya sebesar 61 persen dipengaruhi oleh variabel-variabel lain diluar model penelitian.

Nilai signifikansi uji t untuk variabel religiusitas $\left(\mathrm{X}_{1}\right)$ pada persepsi etis mahasiswa akuntansi sebesar 0,02 dimana lebih kecil dari nilai taraf nyata yaitu 0,05. Religiusitas berpengaruh positif pada persepsi etis mahasiswa akuntansi. Tingkat religiusitas yang tinggi akan berdampak pada semakin tinggi persepsi etis mahasiswa akuntansi. Semakin rendah tingkat religiusitas, persepsi etis yang dimiliki mahasiswa akuntansi akan semakin rendah.

Seseorang dengan religiusitas yang tinggi akan memiliki persepsi dan perilaku etis yang lebih baik. Hal ini sesuai dengan ajaran agama yakni untuk selalu berbuat baik dan berdasarkan pada etika yang ada, sehingga seseorang berusaha berbuat sesuai dengan aturan untuk menghormati ajaran agama. Keyakinan yang tinggi pada ilmu agama akan meningkatkan pemahaman akan hal yang benar dan salah serta boleh dan tidak dilakukan.

Rasa takut, berdosa, bersalah apabila berlaku tidak sesuai dengan ajaran agama akan meningkatkan persepsi dan perilaku seseorang. Tingkat religiusitas yang tinggi juga akan memberikan gambaran akan hukum karma atau hukuman yang harus diterima apabila melanggar ajaran agama. Konsep karma menjelaskan bahwa seseorang berperilaku jahat maka dimasa mendatang aka nada hal buruk yang menimpanya, apabila berperilaku baik maka dimasa mendatag aka nada hal baik yang dating dalam hidup. Seseorang yang memiliki pemahaman agama akan berperilaku baik pada orang lain. 
Penelitian ini sejalan dengan hasil penelitian Peterson et al. (2010) dan Grasmick, Bursik dan Cochran (1991) yang menunjukan bahwa tingkat religiusitas akan naik dan turun beriringan dengan persepsi etis, khususnya pada mahasiswa akuntansi. Keyakinan yang kuat pada Tuhan akan mengurangi sikap untuk berperilaku curang atau tidak etis karena percaya bahwa Tuhan ada dimana saja dan mengetahui apapun yang dilakukan oleh semua orang.

Nilai signifikansi uji t untuk variabel status sosial ekonomi $\left(\mathrm{X}_{2}\right)$ pada persepsi etis mahasiswa akuntansi sebesar 0,01 dimana lebih kecil dari nilai taraf nyata yaitu 0,05 . Status sosial ekonomi berpengaruh negatif pada persepsi etis mahasiswa akuntansi. Semakin tinggi status sosial ekonomi, maka akan semakin rendah persepsi etis yang dimiliki mahasiswa akuntansi. Semakin rendah tingkat status sosial ekonominya, semakin tinggi pula persepsi etis yang dimiliki.

Seseorang dengan status sosial ekonomi yang tinggi tentu menginginkan kekuasaan, harta dan pengakuan dari masyarakat akan kemampuannya dibidang ekonomi dan sosial serta menganggap orang lain tidak lebih baik dari dirinya. Pengakuan akan kemampuan dari lingkungan akan membuat seseorang nyaman dan merasa terhormat, namun akan timbul rasa selalu tidak puas akan kondisi yang telah dimiliki. Keinginan berlebih akan pengakuan dari lingkungan akan berdampak pada perilaku rakus, tamak dan mampu melakukan segala cara untuk mencapainya. Kekuasaan dan uang yang didapat tidak akan pernah dirasa cukup dan selalu menginginkan yang lebih banyak lagi.

Seseorang dengan status sosial tinggi akan menganggap orang lain lebih rendah dan tidak lebih baik dari dirinya. Perlakuan yang buruk juga mungkin 
A.A. Gde Ari W. P. dan I Gusti Ayu Nyoman Budiasih. Pengaruh...

timbul karena dirasa terdapat perbedaan level antara dirinya dengan orang lain. Kesuksesan orang lain yakni kekayaan dan kekuasaan akan dianggap sebagai pesaing dan memungkinkan timbulnya perilaku tidak etis untuk menjatuhkan orang tersebut. Sifat rakus, iri hati, kebencian akan berdampak pada hilangnya kesadaran dan melanggar berbagai norma, serta aturan yang ada dimasyarakat.

Penelitian ini sejalan dengan hasil penelitian Prasastianta (2011), Danta dan Ginting (2003) dan Sipayung (2015) yang setuju bahwa seseorang dengan status sosial ekonomi yang tinggi cenderung berperilaku konsumtif dan tidak etis. Seseorang dengan perilaku konsumtif cenderung akan melakukan apapun guna memenuhi kebutuhannya, termasuk perilaku tidak etis. Aturan dan norma yang ada akan dikesampingkan guna memperoleh harta dan kekuasaan melebihi orang lain.

Nilai signifikansi uji t untuk variabel love of money $\left(\mathrm{X}_{3}\right)$ pada persepsi etis mahasiswa akuntansi sebesar 0,00 dimana lebih kecil dari nilai taraf nyata yaitu 0,05. Love of money berpengaruh positif pada persepsi etis mahasiswa akuntansi. Tingkat love of money tinggi akan berdampak pada semakin tinggi persepsi etis yang dimiliki mahasiswa akuntansi. Semakin rendah tingkat love of money yang dimiliki, semakin rendah pula persepsi etis yang dimiliki.

Teori motivasi menjelaskan bahwa manusia memiliki 5 kebutuhan dasar yang harus dipenuhi. Dalam pemenuhannya sebagian besar melibatkan kebutuhan akan uang yang berdampak pada kecintaan berlebih pada uang. Seseorang dengan kecintaan terhadap uang akan memiliki motivasi bekerja yang giat dan baik sehingga dihormati dan menjadi tolok ukur keberhasilan di lingkungannya 
(Pradanti dan Prastiwi, 2014). Love of money akan berguna untuk mengendalikan persepsi etis seseorang, karena seseorang akan berperilaku baik guna mendapatkan penghargaan dan uang yang lebih banyak atas tindakan etisnya.

Sanksi hukum dan sosial akan megakibatkan seseorang enggan untuk berperilaku tidak etis, dan mereka akan kesulitan mendapatkan uang yang berdampak pada tidak terpenuhinya kebutuhan hidup. Love of money akan memacu karir seseorang karena adanya apresiasi baik berupa uang ataupun kekuasaan bagi mereka yang bekerja dengan baik dan berperilaku etis.

Penelitian ini sejalan dengan hasil penelitian Pradanti dan Prastiwi (2014) serta Aprianti (2016) yang berpendapat tingkat love of money akan naik dan turun sejalan dengan pada persepsi etis yang dimiliki. Hasil penelitian Widyaningrum (2012) menunjukan love of money erat kaitannya dengan rasionalitas dan perkembangan moral yang baik, dimana seseorang akan menjadi rasional dalam menilai kebutuhan hidup dan lebih baik dalam memandang kebutuhan akan uang.

Penelitian yang dilakukan diharapkan dapat memberikan kontribusi mengenai penelitian pengaruh religiusitas, status sosial ekonomi, dan love of money pada persepsi etis mahasiswa akuntansi. Hasil uji dalam penelitian ini ditemukan bahwa tingkat religiusitas akan berbanding lurus dengan persepsi etis yang dimiliki mahasiswa, status sosial ekonomi akan memiliki nilai yang berbanding terbalik dengan persepsi etis dan love of money akan berbanding positif dengan persepsi etis yang dimiliki mahasiswa. Penelitian ini memberikan implikasi pada pihak kampus guna memperbaiki sistem pendidikan yang ada dimana tidak hanya berfokus pada ilmu namun juga menekankan pentingnya 
A.A. Gde Ari W. P. dan I Gusti Ayu Nyoman Budiasih. Pengaruh...

kepribadian yang dimiliki seseorang meliputi nilai etika dan kejujuran. Kepribadian merupakan sesuatu yang terdapat dalam diri yang membimbing dan memberi arahan pada tingkah laku individu (Kase, 2017).

\section{SIMPULAN}

Berdasarkan pembahasan hasil penelitian yang telah diuraikan sebelumnya, dapat diambil kesimpulan bahwa mahasiswa akuntansi dengan tingkat religiusitas yang tinggi akan memiliki persepsi etis yang tinggi pula. Religiusitas akan berkaitan dengan ketaatan seseorang pada nilai agama, dimana agama selalu megajarkan untuk berbuat baik. Mahasiswa akuntansi dengan tingkat status sosial ekonomi yang tinggi akan memiliki persepsi etis yang rendah. Status sosial ekonomi yang tinggi akan mengakibatkan seseorang menginginkan harta dan kekuasaan secara berlebih sehingga akan melakukan berbagai cara untuk memperolehnya, termasuk perilaku tidak etis. Mahasiswa akuntansi dengan tingkat love of money yang tinggi akan memiliki persepsi etis yang tinggi. Seseorang akan berperilaku baik guna mendapatkan penghargaan dan uang yang lebih banyak atas tindakan etisnya. Sanksi hukum dan sosial akan megakibatkan seseorang enggan untuk berperilaku tidak etis.

Berdasarkan pembahasan hasil penelitian yang telah diuraikan sebelumnya, penelitian ini memiliki keterbatasan yakni hanya dilakukan pada mahasiswa program studi akuntansi Fakultas Ekonomi dan Bisnis Universitas Udayana. Sampel tidak menyebar keseluruh angkatan hanya pada satu angkatan. Variabel yang dipergunakan masih terbatas dan belum proporsionalnya jumlah responden pria dan wanita. Berdasarkan simpulan dan keterbatasan penelitian 
yang ada, maka direkomendasikan saran bahwa penelitian selanjutnya dapat memperluas ruang lingkup penelitian dengan sampel mahasiswa dari berbagai universitas dan angkatan. Peneliti selanjutnya diharapkan mampu menggunakan metode wawancara guna mendapatkan data yang lebih akurat dengan semakin rendahnya kesalahpahaman responden dalam menilai pertanyaan yang diberikan. Peneliti menyarankan kepada pihak kampus untuk meningkatkan pemahaman dan kepercayaan konsep agama dalam dunia bisnis di kampus. Perlu adanya penambahan mata kuliah ataupun waktu khusus mengenai bisnis dalam kaitannya dengan keagamaan, dikarenakan pada hasil kuesioner pernyataan bekerja keras untuk mengembangkan bisnis sesuai dengan ajaran agama memiliki skor yang rendah dibandingkan dengan pernyataan lainnya. Peneliti selanjutnya diharapkan mengembangkan penelitian ini dengan meneliti faktor lain seperti individualisme, maskulinitas dan faktor lainnya yang belum diteliti oleh peneliti dikarenakan faktor tersebut berpengaruh terhadap persepsi etis seseorang. Orang dengan sikap individualisme yang tinggi akan mementingkan diri sendiri dan tidak mementingkan orang lain. Maskulinitas akan mempengaruhi pandangan seseorang akan hal yang benar dan salah (penggunaan otak kiri dan kanan). Perilaku etis dipengaruhi oleh tingkat maskulinitas seseorang. 
A.A. Gde Ari W. P. dan I Gusti Ayu Nyoman Budiasih. Pengaruh...

\section{REFERENSI}

Adi, Rianto, (2008), Metodologi Penelitian Sosial dan Hukum, Yayasan Obor Indonesia, Jakarta.

Allport, G. W. (1950) The individual and his religion: a psychological interpretation, Macmillan paperbacks. Tersedia pada: http://lib.cityu.edu.hk/record=b1549815.

Anderson, G. M. (1988) "Mr. Smith and the Preachers: The Economics of Religion in the Wealth of Nations," Journal of Political Economy, 96(5), hal. 1066-1088. doi: 10.2307/1837247.

Aprianti, V. (2016) "Pengaruh Usia, Gender, Status Sosial Ekonomi dan Pengalaman Kerja Terhadap Persepsi Etis Mahasiswa Akuntansi dengan Love of Money Sebagai Variabel Intervening." Tersedia pada: http://repository.umy.ac.id/handle/123456789/898.

Aziz, toriq ibnu (2015) "PENGARUH LOVE OF MONEY DAN MACHIAVELLIAN TERHADAP PERSEPSI ETIS MAHASISWA AKUNTANSI (Studi," IV(I), hal. 4140-4143. doi: 10.1016/j.jdermsci.2014.05.009.

Basri, Y. M. (2015) "Pengaruh gender, religiusitas dan sikap love of money pada persepsi etika penggelapan pajak mahasiswa akuntansi," Jurnal Ilmiah Akuntansi dan Bisnis, 10(1), hal. 45-54.

Basrowi dan Siti, J. (2010) "Analisis kondisi sosial ekonomi dan tingkat pendidikan masyarakat Desa Srigading, Kecamatan Labuhan Maringgai, Kabupaten Lampung Timur," Jurnal Ekonomi \& Pendidikan, 7(1), hal. 58-81.

Charismawati, C. D. (2011) "Analisis hubungan antara love of money dengan persepsi etika mahasiswa akuntansi," Universitas Diponegoro. Tersedia pada: http://eprints.undip.ac.id/29310/1/Jurnal_Celvia_Dhian_C.pdf.

Dahlan, A. (2008) "Ilmu, Etika, dan Agama: Representasi Ilmu Ekonomi Islam Ahmad," Ibda', 6(1), hal. 71-90.

Danta, E. K. A. dan Ginting, J. (2003) "HUBUNGAN PERSEPSI TERHADAP PROGRAM PENGEMBANGAN KARIR DENGAN KOMPETISI KERJA," hal. 1-17.

Elias, R. Z. dan Farag, M. (2010) “The relationship between accounting students' love of money and their ethical perception," Managerial Auditing Journal, 25(3), hal. 269-281. doi: 10.1108/02686901011026369.

Frederickson, N., Miller, a dan Cline, T. (2008) "Educational Psychology," Educational Psychology, 77, hal. 41-64. doi: 


\subsection{7/CBO9781107415324.004.}

Furnham, A. (1984) "Many Sides Psychology of the Coin : the of Money Usage," Personality and Individual Differences, 5(5), hal. 501-509.

Ghozali (2013) Aplikasi Analisi Multivariate dengan menggunakan SPSS, Gramedia.

Ghozali, I. (2012) Statistik Non-Parametrik: Teori dan Aplikasi dengan Program SPSS, Universitas Diponegoro. Semarang.

Ghozali, I. (2013) "Aplikasi Analisis Multivariate Dengan Program IBM dan SPSS.," in aplikasi analisis multivariate dengan program ibm spss 19, hal. 113. doi: 10.2307/1579941.

Glock, C. Y. (1962) "On the study of religious commitment," Religious Education, 57, hal. 98-110. doi: 10.1080/003440862057S407.

Grasmick, H. G., Bursik, R. J. dan Cochran, J. K. (1991) “'RENDER UNTO CAESAR WHAT IS CAESAR'S': Religiosity and Taxpayers' Inclinations to Cheat," Sociological Quarterly, 32(2), hal. 251-266. doi: 10.1111/j.1533-8525.1991.tb00356.x.

Gray, R., Bebbington, J. dan McPhail, K. (1994) "Teaching ethics in accounting and the ethics of accounting teaching: Educating for immorality and a possible case for social and environmental accounting education," Accounting Education, 3(1), hal. 51-75. doi: 10.1080/09639289400000005.

Hasibuan, M. S. P. (2011) "Manajemen Sumber Daya Manusia," Edisi Revisi Jakarta: Bumi Aksara. doi: 10.1017/CBO9781107415324.004.

http://ekonomi.kompas.com/read/2016/10/13/200000526/skandal.akuntansi.goyan g.merek.toshiba. Diakses tanggal 1, bulan Agustus, tahun 2017.

https://news.detik.com/berita/d-3442042/kasus-e-ktp-rp-23-t-kerugian-negara-2tersangka-dan-280-saksi. Diakses tanggal 1, bulan Agustus, tahun 2017.

https://m.tempo.co/read/news/2017/04/27/063870205/kasus-korupsi-al-qurankpk-tetapkan-fadh-el-fouz-tersangka. Diakses tanggal 1, bulan Agustus, tahun 2017.

http://ww2.prospects.ac.uk/cms/ShowPage/Home_page/Main_Menu_News_and_i nformation/Graduate_Market_Trends/Examples_of types_of_work/p!edX ffi. Diakses tanggal 18, bulan Oktober, tahun 2017.

https://www.nolo.com/legal-encyclopedia/unskilled-work-semi-skilled-workskilled-work-social-security-disability.html. Diakses tanggal 18, bulan Oktober, tahun 2017. 
A.A. Gde Ari W. P. dan I Gusti Ayu Nyoman Budiasih. Pengaruh...

Ika, D. (2011) "Pengaruh Kecerdasan Emosional dan Spiritual Terhadap Sikap Etis Mahasiswa Akuntansi Dipandang dari Segi Gender," hal. 129.

Kase, M. S. (2017) Conscientiousness dan Agreeableness Sebagai Pemoderasi Pengaruh Love of Money pada Tax Evasion Tendency Mahasiswa Magister Akuntansi. Udayana.

Kotler, K. (2014) "Manajemen Pemasaran," Manajemen Pemasaran, 0(1), hal. 111. doi: 10.1890/09-2296.1.Abrams.

Luna-Arocas, R. dan Tang, T. L. P. (2004) "The love of money, satisfaction, and the protestant work ethic: Money profiles among university professors in the U.S.A. and Spain," Journal of Business Ethics, 50(4), hal. 329-354. doi: 10.1023/B:BUSI.0000025081.51622.2f.

Maslow, A. H. (1955) "Motivation and Personality," Motivation and personality., hal. 62-27. doi: 10.1037/h0039764.

McGee, R. W. dan Cohn, G. M. (2008) "Jewish Perspectives on the Ethics of Tax Evasion," Journal of Legal, Ethical and Regulatory Issues, 11(2), hal. 132. doi: 10.1007/s10551-006-9002-z.

Mulawarman, A. D. (2012) "METAMORFOSIS KESADARAN ETIS HOLISTIK MAHASISWA AKUNTANSI Implementasi Pembelajaran Etika Bisnis dan Profesi berbasis Integrasi IESQ," Simposium Nasional Akuntansi XIII Ikatan Akuntan Indonesia Komisi Akuntan Pendidik. Universitas Jendral Soedirman, Purwokerto, hal. 81-87. doi: 10.1007/s13398-014-0173-7.2.

Noe, R. A. dan Liu, X. (2006) "Human resource management," Human Resource Management, hal. London. doi: 10.1080/09585199200000162.

O'Leary, C. dan Cotter, D. (2000) "The ethics of final year accountancy students: an international comparison," Managerial Auditing Journal, 15(3), hal. 108-115. doi: 10.1108/02686900010319366.

O'Leary, C. dan Pangemanan, G. (2007) "The effect of groupwork on ethical decision-making of accountancy students," Journal of Business Ethics, 75(3), hal. 215-228. doi: 10.1007/s10551-006-9248-5.

Peterson, R.A., Albaum, J.Merunka, D., Munuera, J.L. dan Smith, S.M, (2010), Effects of Nationality, Gender, and Religiosity on Business-Related Ethicality, Journal of Business Ethics, 96(4), pp, 573-587. doi: 10.1007/s10551-010-0485-2.

Pope, J. dan Mohdali, R. (2010) "The role of religiosity in tax morale and tax compliance," Australian Tax forum, 25(January 2011), hal. 565-596. 
Pradanti, N. R. dan Prastiwi, A. (2014) "ANALISIS PENGARUH LOVE OF MONEY TERHADAP PERSEPSI ETIS MAHASISWA AKUNTANSI," DIPONEGORO JOURNAL OF ACCOUNTING, 3(3), hal. 1-12. Tersedia pada: http://ejournal-s1.undip.ac.id/index.php/dbr.

Purnamasari, S. V. (2006) "Sifat Machiavellian dan Pertimbangan Etis: Anteseden Independensi dan Perilaku Etis Auditor," Simposium Nasional Akuntansi IX, 812256908, hal. 23-26.

Richmond, K. A. (2001) "Ethical reasoning, Machiavellian behavior, and gender: The impact on accounting students' ethical decision making," ProQuest Dissertations and Theses, hal. 85-85 . doi: 10.1017/CBO9781107415324.004.

Schunk, D. H. (2012) Learning theories, Printice Hall Inc., New Jersey. doi: 10.1017/CBO9781107415324.004.

Sipayung (2015) ANALISIS PENGARUH ASPEK DEMOGRAFI, STATUS SOSIAL EKONOMI DAN PENGALAMAN KERJA TERHADAP PERSEPSI ETIS MAHASISWA AKUNTANSI DENGAN LOVE OF MONEY SEBAGAI VARIABEL INTERVENING.

Sugiyono (2014) Metode Penelitian Pendidikan Pendekatan Kuantitatif, Kualitatif dan $R \& D$, Metode Penelitian Pendidikan Pendekatan Kuantitatif, Kualitatif Dan R\&D. doi: 10.1007/s13398-014-0173-7.2.

Tang, T. L. P. dan Chiu, R. K. (2003) "Income, Money Ethic, Pay Satisfaction, Commitment, and Unethical Behavior: Is the Love of Money the Root of Evil for Hong Kong Employees?," Journal of Business Ethics, 46(1), hal. 13-30. doi: 10.1023/A:1024731611490.

Uno, H. H. B. (2010) Model pembelajaran: menciptakan proses belajar mengajar yang kreatif dan efektif, Jakarta: Bumi Aksara. doi: 10.1038/cddis.2011.1.

Widyaningrum, A. (2012) "Determinan Persepsi Etika Mahasiswa Akuntansi dengan Love of Money Sebagai Variabel Intervening," (7), hal. 1-28.

Yamauchi, K. T. dan Templer, D. I. (1982) "The Development of a Money Attitude Scale," Journal of Personality Assessment, 46(5), hal. 522-528. doi: 10.1207/s 15327752jpa4605_14. 